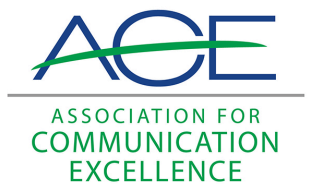

Journal of Applied Communications

\title{
The Message or the Channel: An Experimental Design of Consumers' Perceptions of a Local Food Message and the Media Channels Used to Deliver the Information
}

Jessica Holt

Joy N. Rumble

Ricky Telg

See next page for additional authors

Follow this and additional works at: https://newprairiepress.org/jac (c) (i) (3)

This work is licensed under a Creative Commons Attribution-Noncommercial-Share Alike 3.0 License.

\section{Recommended Citation}

Holt, Jessica; Rumble, Joy N.; Telg, Ricky; and Lamm, Alexa (2015) "The Message or the Channel: An Experimental Design of Consumers' Perceptions of a Local Food Message and the Media Channels Used to Deliver the Information," Journal of Applied Communications: Vol. 99: Iss. 4. https://doi.org/10.4148/ 1051-0834.1053

This Research is brought to you for free and open access by New Prairie Press. It has been accepted for inclusion in Journal of Applied Communications by an authorized administrator of New Prairie Press. For more information, please contact cads@k-state.edu. 


\title{
The Message or the Channel: An Experimental Design of Consumers' Perceptions of a Local Food Message and the Media Channels Used to Deliver the Information
}

\begin{abstract}
With the ever-increasing options of communication media channels, the question of, "Which media channel is the best for a message?" is an important question for researchers and professionals in the agricultural arena. This research sought to determine how the interaction between consumers' perceptions of the message and past media use impacted their attitudes toward the media channels of print, video, and Web. The theoretical framework used in this study was media richness, which was used to understand the characteristics of different media channels and their ability to deliver information. The message used in this study was related to buying local food in Florida. This study used an experimental design to assess respondents' attitudes toward media channels. The population for the study was Florida consumers, and a non-probability sample was used. The 1,122 respondents' of this study were given a message through one of the three media channels of a print, video, or Web advertisement and then asked their perceptions of the message and the media channel. The results indicated respondents' attitudes toward the channel were significantly impacted by their perception of the message but not their past media usage. Recommendations for future research of theory and professional application are given.
\end{abstract}

\section{Keywords}

Attitude toward media channels, message perceptions, media richness, media channel perceptions, past media use, agricultural messages, local food messages, Association for Communication Excellence Conference

\section{Authors}

Jessica Holt, Joy N. Rumble, Ricky Telg, and Alexa Lamm 


\title{
The Message or the Channel: An Experimental Design of Consumers' Perceptions of a Local Food Message and the Media Channels Used to Deliver the Information
}

\author{
Jessica Holt, Joy N. Rumble, Ricky Telg, and Alexa Lamm
}

\section{Abstract}

With the ever-increasing options of communication media channels, the question of, "Which media channel is the best for a message?" is an important question for researchers and professionals in the agricultural arena. This research sought to determine how the interaction between consumers' perceptions of the message and past media use impacted their attitudes toward the media channels of print, video, and Web. The theoretical framework used in this study was media richness, which was used to understand the characteristics of different media channels and their ability to deliver information. The message used in this study was related to buying local food in Florida. This study used an experimental design to assess respondents' attitudes toward media channels. The population for the study was Florida consumers, and a non-probability sample was used. The 1,122 respondents' of this study were given a message through one of the three media channels of a print, video, or Web advertisement and then asked their perceptions of the message and the media channel. The results indicated respondents' attitudes toward the channel were significantly impacted by their perception of the message but not their past media usage. Recommendations for future research of theory and professional application are given.

\section{Key Words}

Attitude toward media channels, message perceptions, media richness, media channel perceptions, past media use, agricultural messages, and local food messages

\section{Introduction and Theoretical Framework}

Starting with print media, then progressing to radio, television, Internet, and now interactive technology, the communication field has experienced different channels and methods for connecting with consumers (McQuail, 2010; Severin \& Tankard, 2001). With the invention of the printing press, the ability to share printed material for information and entertainment became more popular for delivering messages to consumers (McQuail, 2010). Television has progressed from black and white projections to digital television that enables users to access thousands of choices of channels with high-resolution graphics and messages (Severin \& Tankard, 2001). The Internet has expanded

The Florida Department of Agriculture and Consumer Services and the U.S. Department of Agriculture provided funding for this study through a specialty crop block grant. This manuscript was part of a larger study. A version of this manuscript was presented at the 2015 Association for Communication Excellence (ACE) Conference in Charleston, South Carolina. 
upon both of these channels to allow users to create and explore information that interests them (Liu \& Shrum, 2002; McQuail, 2010).

Similar to the industrial revolution and the "information revolution," the way in which information has been communicated and disseminated has been changing with the growth and addition of communication technology (Mulhern, 2009). With this technological revolution, the ways in which ideas and information can be passed along to consumers has changed. The changing atmosphere in communication, known as "media convergence," has led to communicators utilizing all forms of communication channels to reach audiences (Severin \& Tankard, 2001). An integral part of the communication profession has included understanding and utilizing the most effective media channel to connect with consumers because the media channel can impact consumers' perceptions about the message with the varying capabilities of the channel (Bennett, 2010).

Regardless of the message, consumers form attitudes about a message based on the source and choose to either accept or reject a message based on their trust and level of comfort with the source of the message (Bennett, 2010; Eiser, Miles, \& Frewer, 2002; Frewer, Howard, Hedderley, \& Shepherd, 1996). Also, visual and verbal components incorporated with the message can influence individuals' attitudes about a product and attitudes about a brand in general (Mitchell, 1986). Knowing consumers form opinions about a message based on the source or channel adds significance to the need for communication specialists to understand the audience and tailor the message and media channel to the preferences of the target audience (Ledford, 2012). Ledford (2012) gave the example that a person comfortable with using text messaging "could assess the language of texting as more natural than the formal language of a business letter, whereas someone in the older demographic may find the formality more natural than the 'shorthand of texting"' (p. 178).

While much research has been published about the effectiveness of utilizing multiple media channels for marketing purposes (Mulhern, 2009; Schooler, Chaffee, Flora, \& Roser, 1998), little has been published about which media channel has been most effective for delivering specific information to consumers. Studies have established that communicators have had many media channels to choose from when implementing a marketing strategy; however, what consumers choose to do and how they process the messages received through those media channels has not been discussed sufficiently (Webster \& Ksiazek, 2012). With technological communication advances, consumers and marketing professionals have many different communication channels available to them in the $21^{\text {st }}$ century. Consumers have preferences for media channels; "those preferences might reflect user needs, moods, attitudes, or tastes, but their actions are 'rational' in the sense that they serve those psychological predispositions" (Webster \& Ksiazek, 2012, p. 41). By having more knowledge about consumers' media channel preferences, marketing campaigns can be implemented with that information in mind (Ledford, 2012).

Many of the messages consumers have received have been related to the food they eat. "Food is quickly becoming a powerful symbol in the struggle to transition to a more sustainable pathway, and interest surrounding food has been increasing steadily" (Kerton \& Sinclair, 2010, p. 401). Consumers have had many choices when deciding what foods and products to buy for their families. One of the choices available to consumers, in relation to the types of foods and products they choose to buy, is locally grown food (Onken \& Bernard, 2010). Eating locally grown food has been a growing trend in communities within the U.S. to foster connectedness between consumers and their communities, create relationships with those individuals who grow and produce their food, and revitalize local communities (Schnell, 2013). Local food markets have allowed small farmers to sell their goods

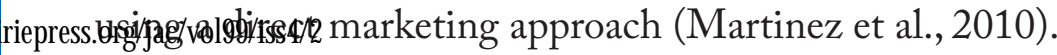


Locally grown food has been growing in prominence as an interest with those consumers who are concerned about how their food has been grown and produced (Schnell, 2013). Research has shown consumers are flexible in their personal definition of the term "local" based on the type of food they are purchasing and their regional location (Conaway \& Rumble, 2013). Since it has been shown the definition of "local" may span across a state or even across a region, communication specialists have employed a variety of marketing materials to reach consumers. Communication efforts in promoting locally grown food have ranged from TV commercials, print materials (brochures, signage, and advertisements), Websites, and word-of-mouth advertising (Martinez et al., 2010). However, no information has been made available related to which media channel has been most effective for conveying the message about buying locally grown food to consumers. With this in mind, importance should be placed on understanding which media channel(s) has the most potential to effectively encourage consumers to buy locally grown food.

This research was specifically interested in examining the channel's impact on the individual's attitude toward buying local food, specifically Florida-grown blueberries. The following research objective guided this study:

RO: Determine the effect the interaction between media channel and past media use has on attitude toward channel, when controlling for perception of message.

Also, one hypothesis was used in this study, based on previous research related to consumers' media usage, and was used in guiding this research:

$\mathrm{H}_{1}$ : $\quad$ Subjects will have a more favorable attitude toward media channel when exposed to the Web media channel than when exposed to the print or video media channels.

\section{Media Richness}

Different forms of media (i.e. print, video, and Web media) have the ability to convey information based on their characteristics and capacity (Carlson \& Zmud, 1999). "Media richness, then, refers to the channels' relative abilities to convey messages that communicate rich information" (Carlson \& Zmud, 1999, p. 154). A "rich" media channel has been shown to have the ability to deliver complex information because of its characteristics of providing feedback, multiple cues, language diversification, and personalization; whereas, a "lean" media channel has been shown to best convey simple information with a limited amount of information based on its characteristics (Pieterson, Teerling, \& Ebbers, 2008). A media channel's "richness" or "leanness" has been based on the following characteristics: "immediate feedback, the number of cues and channels used, personalization, and language variety” (Pieterson et al., 2008, p. 220).

Immediate feedback refers to the ability to interact and receive feedback about a message, number of cues refers to the ability to deliver the message in multiple ways (video, print, and Web), personalization refers to the ability to manipulate the message for the intended receivers, and language refers to the ability to alter the words within the message (Pieterson et al., 2008). "Rich" media channels have been shown to contain all of the four characteristics; whereas, "lean" media channels have been shown to be lacking one or more of the characteristics (Pieterson et al., 2008). The theory of media richness was introduced and designed by Daft and Lengel in 1984 (Daft \& Lengel, 1986), with the intent to improve the flow of information and ideas throughout an organization and facilitate growth among the organization (D'Urso \& Rains, 2008). The theory of media richness was 
developed with the idea that each media channel was on a continuum of information capacity (Daft \& Lengel, 1986). Face-to-face communication is considered to have the highest capacity for carrying the most information to the receiver and is a "rich" media channel; whereas, computer spreadsheets and memos are considered the "leanest" media channel because they lack capacity for carrying information (Daft \& Lengel, 1986; D’Urso \& Rains, 2008). "Rich" media channels should be used to convey messages that require a large amount of information to make a decision, and "lean" messages are best for sending small amounts of information (Daft \& Lengel, 1986). A "rich" media channel cannot be used in a "lean" situation because too much superfluous information is provided (Daft \& Lengel, 1986). Also, "lean" media channels cannot be used in a situation that requires a "rich" media channel because they lack the ability to give enough information and lead to miscommunication and confusion (Daft \& Lengel, 1986). Therefore, the appropriate media channel must be decided based on the situation.

Communication professionals have used the theory of media richness to determine which media channel was most appropriate for a given message; however, "we have moved to an era of dialogic communication campaigns in which the public has more power in controlling message design and delivery" (Ledford, 2012, p. 176). Ledford (2012) discussed the emergence of the idea that allowed communication practitioners to determine which communication channel would be the most appropriate to use in disseminating their message because the type of message plays a critical role in media channel selection. The control level of the message is primarily dictated by the design and delivery of the message (Ledford, 2012). The amount of control affects the type and amount of feedback consumers give. Ledford (2012) suggested that communication professionals should analyze their audience and message to determine how rich the media should be and how much control is needed. Once those factors are determined, the communicators should then use typology channel selection figure (Figure 1) to determine which media channel would be most effective for their message (Ledford, 2012).

\section{Methods and Procedures}

For this study, a posttest-only experimental design was used to determine which media channel had the most impact on consumer attitude toward the media channel. This research used a withinsubjects design. For this study, respondents were randomly assigned to one treatment, and then past use of media, attitude toward the media channel and perception of the message were assessed.

The posttest-only study design guided the experimental groups using the following designations: $\mathrm{R}=$ random assignment, $\mathrm{X}_{(\mathrm{i})}=$ treatment level, and $\mathrm{O}_{(\mathrm{j})}=$ observation of treatment effect. $\mathrm{X}_{(1)}=$ print media channel, $\mathrm{X}_{(2)}=$ video channel, and $\mathrm{X}_{(3)}=$ Web media channel.

A convenience sample of consumers within the state of Florida was used for this study. Although the findings from this research cannot be generalized to a broader population because of the use of a convenience sample, the findings may be applied cautiously to specific populations (McMillan \& Schumacher, 2010). "Convenience samples are widely used in both quantitative and qualitative studies because this may be the best the researcher can accomplish due to practical constraints, efficiency, and accessibility" (McMillan \& Schumacher, 2010, p. 137).

To establish the sampling frame for this study, first the population was determined to be all adult consumers within the state of Florida. The U.S. Census Bureau's most up-to-date data for the state of Florida was used. The population size according to the U.S. Census Bureau in 2010 was 18,801,310 (U.S. Census Bureau, 2014). Since it was not economically or logistically possible to obtain a random

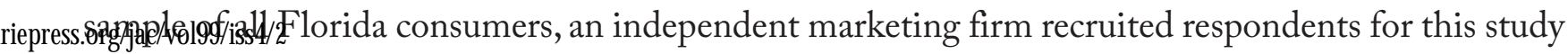




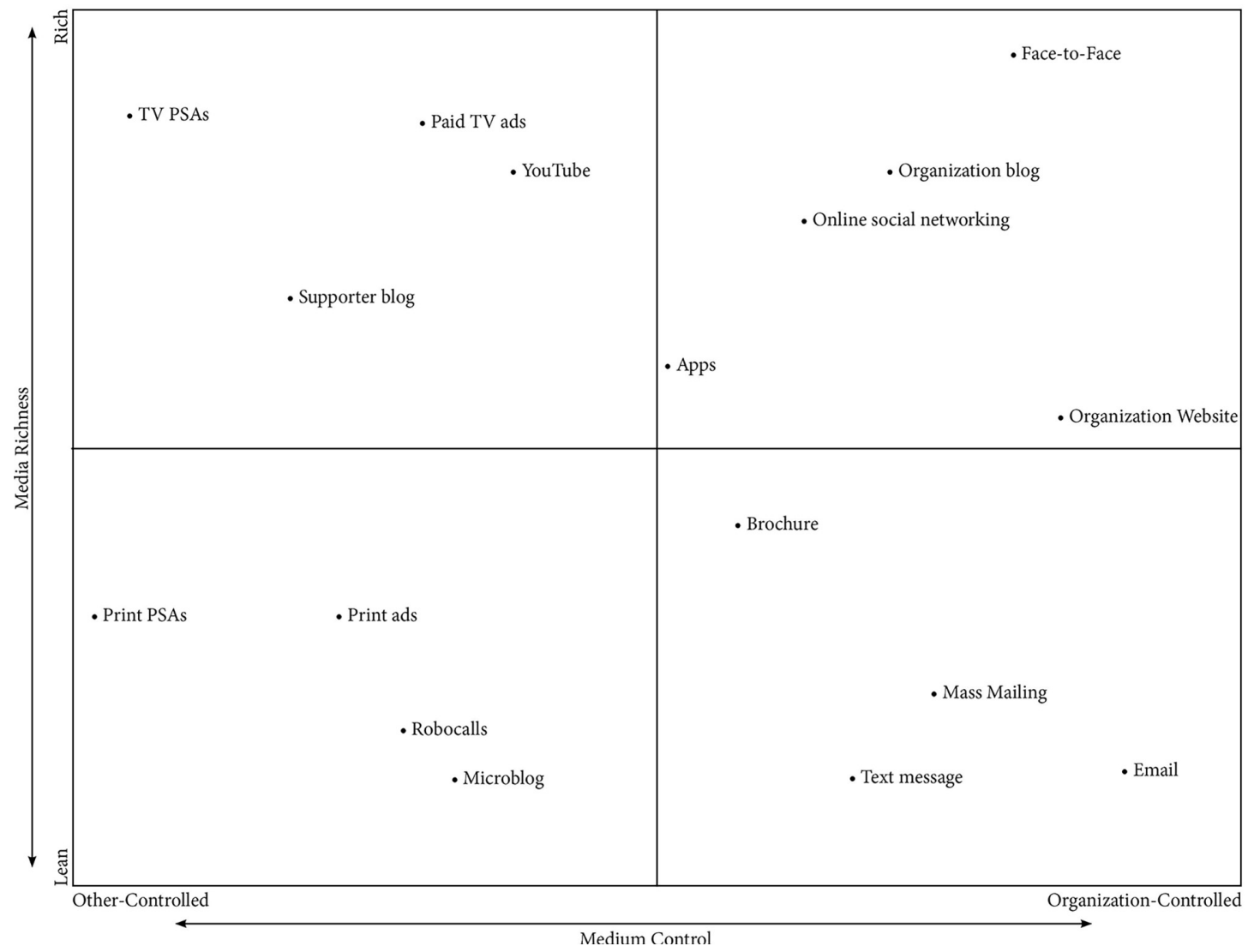

Figure 1. Media richness channel selection

through the Internet. In order to obtain an acceptable level of power, the sample size was calculated using an online computer program: National Statistical Service Sample Size Calculator (National Statistical Service, 2014). The programs have been shown to give the most accurate calculations for sample size (Keppel \& Wickens, 2004). Using a confidence level of 95\%, the population size of $18,801,301$, a confidence interval of .05 , the needed sample size was determined to be 385 for each treatment, for a total of 1,155 respondents ( 3 treatments $x 385=1,155$ ).

When conducting research, a probability sample is ideal (Baker et al., 2013); however, as technology changes the way in which people choose to interact and communicate with the world, the ways to involve them in research is subject to change as well (Ruggiero, 2000). This change also impacts research, in that researchers are tasked with the challenge of reaching populations using a variety of communication channels (Baker et al., 2013; Hovland, 1959; Ruggiero, 2000). As of 2013, only 15\% of the population ages 18 to 30 did not have access to the Internet (Zickur \& Smith, 2013) and landlines for random digit dialing (RDD) are not the norm for all households (Baker et al., 2013; Zickur \& Smith, 2013). In fact, Baker et al. (2013) reported that relying on landlines for RDD might not be a true representation of a probability sample anymore because of the differences in individuals who have a landline and those who do not.

With that in mind, Internet research has become increasingly popular because researchers are able to reach millions of respondents by utilizing opt-in panels for research (Baker et al., 2013). Optin panels recruit individuals to participate in studies utilizing the Internet and computer-mediated survey software (Baker et al., 2013). This study utilized an opt-in panel determined by SSI, based on the sampling frame discussed above.

The design of the study was a true random experiment (Kirk, 2013), in which respondents only received one treatment and their attitudes toward the channel and perception of the message was 
measured once. The treatments were pretested with a convenience sample of college students at a large, southeastern university because they were included in the population of Florida consumers. These respondents were used because they would not be included in the final sample. The pretest indicated the design of the study accessed respondents' attitudes about a channel and perception of the message; in turn, the research question and objective of the study were able to be answered using the design.

The researcher created the survey in Qualtrics and then sent the hyperlink for the instrument to the overseeing account manager at Survey Sampling International (SSI) to disseminate to the recruited respondents. The respondents were given 10 days to complete the survey. SSI sent an initial email recruiting respondents to participate in the study. This research was part of a larger, grant-funded study, which requested 1,155 responses for the quantitative measure from consumers. The research was funded by a specialty crop block grant by the U.S. Department of Agriculture and the Florida Department Agriculture and Consumer Services. SSI continued to recruit respondents to take part in the study until 1,155 usable responses were obtained. The completed responses were collected over a period of five days. SSI ensured respondents were only sent one email opportunity to participate in the study and utilized tracking software to prevent users from completing the survey more than once. Within the instrument, the respondents were given directions and the researcher's contact information.

After collecting the data from the Qualtrics survey, the data were analyzed using SPSS ${ }^{\circledR}$ 22.0. The researcher completed an exploratory analysis of the data to check the quality of data prior to a more in-depth data analysis (Kirk, 2013). Then respondents' demographic information was analyzed for frequencies. The data were also weighted using the 2010, the most up-to-date, data from the U.S. Census Bureau for the state of Florida's demographics. The data were weighted on the demographics of race, ethnicity, gender, and age. After verifying the data, the researcher conducted an analysis of variance to answer the study's hypothesis. To ensure internal consistency, a Cronbach alpha coefficient of reliability was calculated. The scale for perception of message had a Cronbach's Alpha of .903 with six items. The scale used to measure attitude toward the media channel used five items and had a Cronbach's Alpha of .908.

\section{Results and Findings}

To test and answer the research objective of this study, the three different treatments of the media channel and the questionnaire were taken by a total of 1,794 respondents; however, 1,122 respondents completed the survey, for a participation rate of $62.5 \%$. Respondents did not complete the survey and were removed from the data set because they chose not to participate in the study $(n=84)$, were not over the age of $18(n=3)$, did not live in the state of Florida $(n=15)$, had not purchased blueberries in the last three years $(n=247)$, did not pass the first quality check measure $(n=74)$, did not pass the second quality check measure $(n=149)$, or were not able to see the treatment $(n=100)$. Of the respondents who completed the instrument, 410 (36.5\%) were given the print treatment, 392 (34.9\%) were given the video treatment, and 320 (28.5\%) were given the Website treatment.

The respondents were asked to provide their demographics for gender, age, race, ethnicity, and type of residency. Five hundred and ninety two (52.8\%) were female, and 530 (47.2\%) were male. Respondents ranged in age from 18-19 years of age accounting for 16 (1.4\%) respondents, 150 (13.4\%) were between 20-29, 157 (14.0\%) were between 30-39, 160 (14.3\%) were between the ages of 40-49, 253 (22.5\%) were between 50-59, 256 (22.8\%) were between 60-69, 114 (10.2\%) 
race ranged from 936 (83.4\%) being White, 137 (12.2\%) being Black, 46 (4.1\%) being Asian, 18 (1.6) being American Indian or Pacific Islander, and 5 (.4\%) were of other race. Fifty three of the respondents (4.7\%) identified themselves as Hispanic or Latino/a ethnicity, while 1,069 (95.3\%) did not recognize themselves as Hispanic or Latino/a ethnicity (3). The type of residency the respondents lived in varied from 6 (.5\%) living on farms, 107 (9.5\%) living in rural areas that were not farms, 471 (42.0\%) living in an urban area, 471 (42.0\%) living in suburban areas, and 67 (6.0\%) living in downtown areas (see Table 1).

Table 1. Demographics Florida Census and sample for weighting

\begin{tabular}{|c|c|c|c|c|}
\hline & $\begin{array}{l}\text { Florida } 2010 \\
\text { Census pop. }\end{array}$ & $\begin{array}{c}\text { Florida } 2010 \\
\text { Census \% }\end{array}$ & $\underset{n}{\text { Sample }}$ & $\underset{\%}{\text { Sample }}$ \\
\hline \multicolumn{5}{|l|}{ Gender } \\
\hline Female & $9,611,955$ & 51.2 & 592 & 53.2 \\
\hline Male & $9,189,355$ & 48.8 & 530 & 46.8 \\
\hline \multicolumn{5}{|l|}{ Age } \\
\hline 19 and younger & $4,048,641$ & 23.9 & 16 & 1.4 \\
\hline $20-29$ & $2,407,985$ & 12.8 & 153 & 13.6 \\
\hline $30-39$ & $2,288,785$ & 12.2 & 160 & 14.2 \\
\hline $40-49$ & $2,653,989$ & 14.2 & 160 & 14.3 \\
\hline $50-59$ & $2,542,709$ & 13.5 & 253 & 22.5 \\
\hline $60-69$ & $2,094,483$ & 11.1 & 256 & 22.8 \\
\hline $70-79$ & $1,384,221$ & 7.4 & 114 & 10.2 \\
\hline 80 or over & 916,148 & 4.9 & 16 & 1.4 \\
\hline \multicolumn{5}{|l|}{ Race } \\
\hline White & $14,109,162$ & 75.0 & 936 & 83.4 \\
\hline Black & $2,999,862$ & 16.0 & 137 & 12.2 \\
\hline Asian & 454,821 & 2.4 & 46 & 4.1 \\
\hline American Indian & 71,458 & .4 & 18 & 1.6 \\
\hline Other & 12,286 & .1 & 5 & .4 \\
\hline \multicolumn{5}{|l|}{ Hispanic } \\
\hline Yes & $4,223,806$ & 22.5 & 53 & 4.7 \\
\hline No & $14,577,504$ & 77.5 & 1069 & 95.3 \\
\hline Total & $18,801,310$ & 100.00 & 1122 & 100.00 \\
\hline
\end{tabular}

Since this research utilized a non-probability sample, the coverage error for the sample was analyzed. "Coverage error measures how well a sample frame covers the target population. Under ideal circumstances every member of the target population is listed in the sampling frame and therefore has a chance to be selected for the sample" (Baker et al., 2013, p. 78). To estimate the coverage error in this study, the study's sample demographics were compared to the 2010 Florida Census demographics (see Table 1).

A bipolar, semantic differential scale was used to measure the respondents' perception of the message. Semantic differential scales are used with at least five sets of adjectives to allow researchers to assess respondents' attitude on a given issue or topic (Osgood et al., 1978). The scale used to assess respondents' perception of the message used in this research contained six adjectives. All of the 
responses in the index were reverse coded and one was equal to the negative adjective and five was equal to the positive adjective in order for higher numbers to indicate a more favorable attitude toward the message. The overall grand mean for the index, calculated by averaging responses from each set of adjectives together, was $4.44(S D=.63)$. The reliability index would not have been increased if any item in the index were removed.

To assess respondents' attitudes toward the media channel, a single bipolar, semantic differential scale was used. The scale contained five sets of adjectives. The index's total reliability was $\alpha=.90$ and would not have increased with the removal of any of the items in the index. The grand mean for this index was 4.31 (SD = .74) and was calculated by averaging each of the adjective groups' responses.

The variable of the media channel was used as the treatment in this design. The variable was assessed and analyzed using the indices of perception of the message and attitude toward channel.

The respondents' past media use was measured using a scale adapted from Rosen, Whaling, Carrier, Cheever, and Rokkum (2013). The scale included questions about the respondents' use with specific communication mediums. Questions asked respondents to indicate how often they used the mediums on a daily basis (see Table 2).

Table 2. Past media use

\begin{tabular}{|c|c|c|c|c|c|c|c|}
\hline & $\begin{array}{c}\text { Not at } \\
\text { All } \\
n(\%)\end{array}$ & $\begin{array}{c}\text { Less than } \\
\text { One } \\
\text { Hour } \\
n(\%)\end{array}$ & $\begin{array}{l}1-2 \\
\text { Hours } \\
n(\%)\end{array}$ & $\begin{array}{l}3-4 \\
\text { Hours } \\
n(\%)\end{array}$ & $\begin{array}{l}5-6 \\
\text { Hours } \\
n(\%)\end{array}$ & $\begin{array}{l}7-8 \\
\text { Hours } \\
n(\%)\end{array}$ & $\begin{array}{l}\text { More } \\
\text { than } 8 \\
\text { Hours } \\
n(\%)\end{array}$ \\
\hline Watch TV & $\begin{array}{c}37 \\
(3.3)\end{array}$ & $\begin{array}{c}85 \\
(7.6)\end{array}$ & $\begin{array}{c}253 \\
(22.5)\end{array}$ & $\begin{array}{c}390 \\
(34.8)\end{array}$ & $\begin{array}{c}202 \\
(18.0)\end{array}$ & $\begin{array}{l}65( \\
5.8)\end{array}$ & $\begin{array}{c}90 \\
(8.0)\end{array}$ \\
\hline Browse Websites & $\begin{array}{c}23 \\
(2.3)\end{array}$ & $\begin{array}{c}318 \\
(28.3)\end{array}$ & $\begin{array}{c}413 \\
(36.8)\end{array}$ & $\begin{array}{c}211 \\
(18.8)\end{array}$ & $\begin{array}{c}68 \\
(6.1)\end{array}$ & $\begin{array}{c}40 \\
(3.6)\end{array}$ & $\begin{array}{c}46 \\
(4.1)\end{array}$ \\
\hline $\begin{array}{l}\text { Send/ } \\
\text { Receive emails }\end{array}$ & $\begin{array}{l}6 \\
(.5)\end{array}$ & $\begin{array}{l}393( \\
35.0)\end{array}$ & $\begin{array}{c}422 \\
(37.6)\end{array}$ & $\begin{array}{c}141 \\
(12.6)\end{array}$ & $\begin{array}{c}63 \\
(5.6)\end{array}$ & $\begin{array}{l}35 \\
(3.1)\end{array}$ & $\begin{array}{c}62 \\
(5.5)\end{array}$ \\
\hline $\begin{array}{l}\text { Send/ } \\
\text { Receive phone calls }\end{array}$ & $\begin{array}{c}26 \\
(2.3)\end{array}$ & $\begin{array}{c}604 \\
(53.8)\end{array}$ & $\begin{array}{c}302 \\
(26.9)\end{array}$ & $\begin{array}{c}88 \\
(7.8)\end{array}$ & $\begin{array}{l}38 \\
(3.4)\end{array}$ & $\begin{array}{l}28 \\
(2.5)\end{array}$ & $\begin{array}{c}36 \\
(3.2)\end{array}$ \\
\hline $\begin{array}{l}\text { Participate in social } \\
\text { networking }\end{array}$ & $\begin{array}{c}245 \\
(21.8)\end{array}$ & $\begin{array}{c}368 \\
(32.8)\end{array}$ & $\begin{array}{c}258 \\
(23.0)\end{array}$ & $\begin{array}{c}124 \\
(11.1)\end{array}$ & $\begin{array}{c}56 \\
(5.0)\end{array}$ & $\begin{array}{c}34 \\
(3.0)\end{array}$ & $\begin{array}{c}37 \\
(3.3)\end{array}$ \\
\hline $\begin{array}{l}\text { Send/ } \\
\text { Receive text } \\
\text { messaging }\end{array}$ & $\begin{array}{c}196 \\
(17.5)\end{array}$ & $\begin{array}{c}503 \\
(44.8)\end{array}$ & $\begin{array}{c}207 \\
(18.4)\end{array}$ & $\begin{array}{c}88 \\
(7.8)\end{array}$ & $\begin{array}{c}49 \\
(4.4)\end{array}$ & $\begin{array}{c}38 \\
(3.4\end{array}$ & $\begin{array}{c}41 \\
(3.7)\end{array}$ \\
\hline $\begin{array}{l}\text { Read magazines/ } \\
\text { books }\end{array}$ & $\begin{array}{c}115 \\
(10.2)\end{array}$ & $\begin{array}{c}454 \\
(40.5)\end{array}$ & $\begin{array}{c}370 \\
(33.0)\end{array}$ & $\begin{array}{c}116 \\
(10.3)\end{array}$ & $\begin{array}{c}34 \\
(3.0)\end{array}$ & $\begin{array}{c}13 \\
(1.2)\end{array}$ & $\begin{array}{c}20 \\
(1.8)\end{array}$ \\
\hline
\end{tabular}

The research objective for this study sought to determine the effect the interaction between the media channel and past media use has on attitude toward the channel, when controlling for perception of message. To answer this objective, the data file was split by treatment group and was analyzed using linear regression.

Respondents' past media use was not a significant indicator of respondents' attitude toward the print media channel $\left(F_{31,411}=.57, p=.97\right)$, video media channel $\left(F_{34,403}=.70, p=.89\right)$, or the Web media channel $\left(F_{30,324}=1.24, p=.18\right)$; therefore, the researcher failed to reject the null hypothesis 
Table 3. Interaction between media channel and past media use on attitude toward channel, controlling for perception of the message

\begin{tabular}{lrrrrc}
\hline Variable & \multicolumn{1}{c}{$S S$} & $d f$ & $M S$ & \multicolumn{1}{c}{$F$} & \multicolumn{1}{c}{$p$} \\
\hline Print Media Channel & & & & & \\
Perception of Message & 183.967 & 1 & 183.967 & 1817.572 & .000 \\
Past Media Use & 1.795 & 31 & .058 & .572 & .970 \\
Error & 38.260 & 378 & .101 & & \\
Total & 7756.920 & 411 & & & \\
Video Media Channel & & & & & \\
Perception of Message & 157.695 & 1 & 157.695 & 1236.266 & .000 \\
Past Media Use & 3.071 & 34 & .090 & .708 & .890 \\
Error & 46.814 & 367 & .128 & & \\
Total & 7887.880 & 403 & & & \\
Web Media Channel & & & & & \\
Perception of Message & 84.726 & 1 & 84.726 & 480.773 & .000 \\
Past Media Use & 6.553 & 30 & .218 & 1.240 & .188 \\
Error & 51.459 & 292 & .176 & & \\
Total & 6189.520 & 324 & & & \\
\hline
\end{tabular}

The $\mathrm{R}^{2}$ for each of the media channels was analyzed to understand the variance associated with each treatment group and the respondents' past media use. The print media channel had an $\mathrm{R}^{2}=.840$, the video media channel had an $\mathrm{R}^{2}=.79$, and the Web media channel had an $\mathrm{R}^{2}=.66$. Therefore, the print media channel accounted for $84 \%$, the video media channel accounted for $79.4 \%$, and the Web media channel accounted for $66.6 \%$ of the variance associated with the respondents' past media usage on their attitudes toward the channel, when controlling for perception of message.

The hypothesis proposed for this study was related to respondents' attitude toward the media channel and posited that subjects will have a more favorable attitude toward the media channel when exposed to the Web media channel than when exposed to the print or video media channels.

Upon analysis, respondents held a favorable attitude toward all of the media channels (see Table 4). The print media channel $\left(F_{18,410}=115.70, p=.00\right)$, the video media channel $\left(F_{1,392}=4,812.76, p\right.$ $=.00)$, and the Web media channel $\left(F_{17,320}=3,960.22, p=.00\right)$ were all shown to have a significant impact on respondents' attitude toward the media channel; therefore, the researcher failed to reject the hypothesis. This finding indicated that respondents' attitude toward the channel was predicted by any of the media channels.

Also, the $\mathrm{R}^{2}$ for each of the media channels was analyzed to understand the variance explained by each of the media channels in the model. The print media channel had an $\mathrm{R}^{2}=.842$, the video media channel had an $\mathrm{R}^{2}=.796$, and the Web media channel had an $\mathrm{R}^{2}=.668$. Therefore, the print media channel accounted for $84.2 \%$, the video media channel accounted for $79.6 \%$, and the Web media channel accounted for $66.8 \%$ of the variance associated with the respondents' attitude toward the channel was explained by their perception of the message. 
Table 4. Attitude toward media channel on perception of message when exposed to Web, video, or print media channel

\begin{tabular}{lrrrrr}
\hline Variable & \multicolumn{1}{c}{$S S$} & $d f$ & $M S$ & \multicolumn{1}{c}{$F$} & $p$ \\
\hline Print Media Channel & & & & & \\
Perception of Message & 201.166 & 18 & 11.176 & 115.700 & .000 \\
Error & 77.768 & 391 & .097 & & \\
Total & & & & & \\
Video Media Channel & 574.557 & 1 & 574.557 & 4812.769 & .000 \\
Perception of Message & 44.529 & 373 & .119 & & \\
Error & 7650.160 & 392 & & & \\
Total & & & & & \\
Web Media Channel & 102.198 & 17 & 666.119 & 3960.226 & \\
Perception of Message & 50.797 & 302 & .168 & & \\
Error & 6102.520 & 320 & & & \\
Total & & & & \\
\hline
\end{tabular}

\section{Discussion and Conclusions}

The findings from this research can be applied both theoretically and practically to enhance and grow the body of knowledge in both research and applied communications. When applying the findings from this research, it is important to note the findings from this study are not generalizable to the entire population because a non-probability sample was used for data collection; however, this study can serve a stepping stone to guide future research related to communication media channels used to deliver information about the agricultural industry. Also, this study utilized the commodity of blueberries and the findings cannot be generalized to all commodities.

The individual's past media usage was not a significant indicator of respondents' attitude toward the media channel in this study, which is contradictory to Carlson and Zmud's (1999) model, in that an individual's experiences using a specific channel impact his or her perception of the channel. This finding implies there may be more variables that account for an individual's experience using a specific media channel than just time spent with that channel, as was measured in this study. Other variables that may be of interest would be technology confidence, technology familiarity and availability, and reliance upon technology. Also, individuals' psychographics and their self-identity may be relevant variables to include in future research to understand how media channels impact how individuals receive and process information about the agricultural industry delivered through various communication media channels.

Also, this research revealed that respondents' perception of message was a significant indicator of their attitudes toward the media channel, when the media channel treatment group was controlled. Therefore, no matter which media channel respondents received, their perception of the message directly impacted their attitudes toward the channel. This finding is key for professionals because it corroborates Carlson and Zmud's (1999) idea that how one perceives the message is as an important as the actual media channel used to deliver the information. From a theoretical standpoint, this

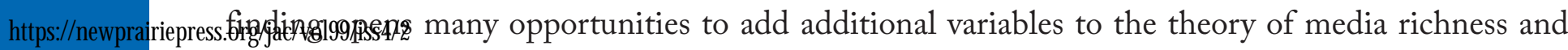


other media channel and perception models to determine the formation, power, and application of individual perceptions, in relation to an individual's attitude toward media channels used to deliver information. From a professional standpoint, this finding suggests that the message used by agricultural companies and organizations should receive more attention in its development and testing to ensure consumers are receptive to the message.

\section{Recommendations}

Based on the findings from this research, it is recommended that professionals not limit the types of media they use to reach consumers based on experience level or past behavior related to media channels. This recommendation is made because of the lack of significance found between the variable of past media use and attitude toward the media channel. Limiting certain media channels to specific target audiences may not be necessary, as indicated by this study. Therefore, the option of media channels available for professionals to use across their target audience can become more comprehensive. However, it should be noted the respondents of this study completed the questionnaire via the Internet, and therefore are inherently different than those consumers not comfortable using the Internet. This is a limitation of the study and should be considered. Future research should be conducted to determine if this finding holds true in other methods of data collection.

This research also indicated none of the media channels (print, video, or Web) had more influence on respondents' attitude toward the media channel than another. This finding is of importance to professionals because this allows the company or organization to use what ever media channel is most accessible for them to reach their target audience; however, it is recommended that more attention be given to how that specific audience perceives the message delivered. Future research should be conducted to determine if this finding holds true among other populations and with the use of other communication technologies, such as smartphones, tablets, etc., as research has shown that people are using technology on an ever-changing basis (Liu \& Shrum, 2002; McQuail, 2010). This study showcases the importance of the message and it is recommended for practitioners to conduct message tests prior to launching a new campaign to their audience.

For research in this area in the future, studies should be conducted that look at testing other modes of communication technology for delivering messages about the agricultural community. The results from this study can only be applied to print, video, and Web media channels. Future research should look at derivations of these media channels as technology broadens these channels'capabilities. For example, future research should be conducted to understand if there are any differences in how consumers' perceive messages when the message is delivered through a static Website versus an interactive Website. In the future, different levels of interactivity of Websites may lead to different findings of how consumers receive and process a message because of having the Internet available for additional information relevant to their lives and the content of the message. As Liu and Shrum (2002) predicted, consumers are using technology in all facets of their lives and this includes how they receive and process information about the agricultural industry.

Also, video advertisements should be studied to determine if any difference lies in how consumers perceive a message delivered through a T.V. video advertisement or a social media video. Similarly, print advertisements are shifting to include additional information through Websites and social media accounts. Research focused on what types of information consumers seek after receiving a message about the agricultural industry would be beneficial for directing future research efforts and practical marketing efforts of professionals in the field.

Based on this research, even though consumers are embracing new and innovative communication 
technologies to receive information, the message delivered through those technologies may be more powerful.

\section{References}

Baker, R., Brick, J. M., Bates, N. A., Battaglia, M., Couper, M. P., Dever, J. A., Gile, K. J., Torangeau, R. (2013). Report of the AAPOR Task Force on non-probability sampling. Journal of Survey Statistics and Methodology. doi: 10.1093/jssam/smt008

Bennett, W. H. (2010). Media and influence. In A. Kott \& G. Citrenbaum (Eds.), Estimating impact: A handbook of computation methods and models for anticipating economic, social, political and security effects in international interventions (pp. 135-178). New York, NY: Springer Science+Business Media, LLC.

Carlson, J. R., \& Zmud, R. W. (1999). Channel expansion theory and the experiential nature of media richness perceptions. Academy of Management Journal, 42(2), 153-170. Retrieved from http://www.jstor.org/stable/257090

Conaway, L., \& Goodwin, J. N. (2013). Florida MarketMaker (Research Report). Retrieved from Center for Public Issues Education in Agriculture and Natural Resources Website: http://www. centerpie.com/wp-content/uploads/2013/01/Florida-MarketMaker-Final-Report.pdf

Daft, R. L., \& Lengel, R. H. (1986). Organizational information requirements, media richness and structural design. Management Science, 32(5), 554-571. Retrieved from http://www.jstor.org/ stable/2631846

D'Urso, S. C. \& Rains, S. A. (2008). Examining the scope of channel expansion: A test of channel expansion theory with new and traditional communication media. Management Communication Quarterly, 21(4), 486-507. doi: 10.1177/0893318907313712

Eiser, J. R., Miles, S., \& Frewer, L. J. (2002). Trust, perceived risk, and attitudes toward food technologies. Journal of Applied Social Psychology, 32(11), 2423-2433. doi: 10.1111/j.15591816.2002tb01871.x

Field, A. (2009). Discovering statistics using SPSS (3 $\left.{ }^{\text {rd }}\right)$. Thousand Oaks, CA: Sage Publications, Inc.

Frewer, L. J., Howard, C., Hedderley, D., \& Shepherd, R. (1996). What determines trust in information about food-related risks? Underlying psychological constructs. Risk Analysis, 16(4), 473-486. doi: 10.1111/j.1539-5924.1996.tb01094.x

Hovland, C. I. (1959). Reconciling conflicting results derived from experimental and survey studies of attitude change. American Psychologist, 14(1), 8-17. doi: 10.1037/h0042210

Keppel, G., \& Wickens, T. D. (2004). Design and analysis a researcher's handbook. $4^{\text {th }}$ ed. Upper Saddle River, NJ: Pearson Education, Inc.

Kerton, S., \& Sinclair, J. A. (2010). Buying local organic food: A pathway to transformative learning. Agricultural and Human Values, 27(4), 401-413. doi: 10.1007/s10460-009-9233-6

Kirk, R. E. (2013). Experimental design: Procedures for the behavioral sciences (4th). Thousand Oaks, CA: Sage Publications, Inc.

Ledford, C. J. W. (2012) Changing channels: A theory-based guide to selecting traditional, new, and social media in strategic social marketing. Social Marketing Quarterly, 18(3), 175-186. doi: $10.177 / 1524500412460671$

Liu, Y., \& Shrum, L. J. (2002). What is interactivity and is it always such a good thing? Implications of definition, person and situation for the influence on interactivity on advertising effectiveness. Journal of Advertising, 31(4), 53-64. Retrieved from http://www.jstor.org/ 
Martinez, S., Hand, M., Da Pra, M, Pollack, S., Ralston, K., Smith, T., ... Newman, C., (2010). Local foods systems concepts, impacts, and issues (Report No. 97). Retrieved from U.S. Department of Agriculture http://www.ers.usda.gov/media/122868/err97_1_.pdf

McMillan, J. H., \& Schumacher, S. (2010). Research in education: Evidence-based inquiry $\left(7^{\text {th }}\right)$. Upper Saddle River, NJ: Pearson Education, Inc.

McQuail, D. (2010). Mass communication theory $\left(6^{\text {th }}\right)$. Thousand Oaks, CA: SAGE Publications, Ltd.

Mitchell, A. A. (1986). The effect of verbal and visual components of advertisements on brand attitudes and attitude toward the advertisement. Journal of Consumer Research, 13(1), 12-24. Retrieved from http://www.jstor.org/stable/2489283

Mulhern, F. (2009). Integrated marketing communications: From media channels to digital connectivity. Journal of Marketing Communications, 15(2-3), 85-101. doi: $10.1080 / 13527260902757506$

National Statistical Service. (2014). Sample size calculator. http://www.nss.gov.au/nss/home.nsf/ pages/Sample+size+calculator

Onken, K .A., \& Bernard, J C. (2010). Catching the "local" bug: A look at state agricultural marketing programs. Choices, 25(1), 1-7. Retrieved from www.choicesmagazine.org

Osgood, C. E., Suci, G. J., \& Tannenbaum, P. H. (1978). The measurement of meaning. Urbana, IL: University of Illinois Press.

Pieterson, W., Teerling, M., \& Ebbers, W. (2008). Channel perceptions and usage: Beyond media richness factors. Electronic Government, 5184, 219-230. doi: 10.1007/978-3-540-85204-9_19

Qualtrics. (2013, June 18). 95 of the top 100 U.S. business schools bave standardized on Qualtrics to conduct cutting-edge research. Retrieved from: http://www.qualtrics.com/press/press-releases/95of-the-top-100-u-s-business-schools-and-qualtrics/

Rosen, L. D., Whaling, K., Carrier, L. M., Cheever, N. A., \& Rokkum, J. (2013). The media and technology usage and attitudes scale: An empirical investigation. Computers in Human Behavior, 29(6), 2501-2511. Doi: 10.1016/j.chb.2013.06.006

Ruggiero, T. E. (2000). Uses and gratifications theory in the $21^{\text {st }}$ century. Mass Communication and Society, 3(1), 3-37. doi:10.1207/S15327825MCS0301

Schooler, C., Chaffee, S. H., Flora, J. A., \& Roser, C. (1998). Health campaign channels tradeoffs among reach, specificity, and impact. Human Communication Research, 24 (3), 410-432. doi: 10.1111/j.1468-2958.1998.tb00423.x

Schnell, S. M. (2013). Deliberate identities: Becoming local in America in a global age. Journal of Cultural Geography, 30(1), 56-89. doi: 10.1070/08873631.2012.745984

Severin, W. J., \& Tankard, J. W. Jr. (2001). Communication theories: Origins, methods, and uses in the mass media $\left(5^{t b}\right)$. New York, NY: Addison Wesley Longman, Inc.

Telg, R. W., \& Irani, T. A. (2012). Agricultural communications in action: A hands-on approach. Clifton Park, NY: Delmar Cengage Learning.

Webster, J. G., \& Ksiazek, T .B. (2012). The dynamics of audience fragmentation: Public attention in an age of digital media. Journal of Communication, 62(1), 39-59. doi: 10.1111/j.14602466.2011.01616.x

U.S. Census Bureau (2014). Profile of general population and housing characteristics: 2010 demographic profile data. Retrieved from http://factfinder2.census.gov/faces/tableservices/jsf/pages/ productview.xhtml?src=bkmk 
Zickuhr, K., \& Smith, A. (2013). Home broadband 2013: Trends and demographic differences in home broadband adoption. Pew Research Internet Project. Retrieved from http://www. pewinternet.org/2013/08/26/home-broadband-2013/

\section{About the Authors}

Jessica Holt is an assistant professor of agricultural communication at the University of Georgia within the Department of Agricultural Leadership, Education and Communication. Her research interests are focused around consumer engagement with food and sustainable living. She is focused on connecting consumers with local farmers and producers using technology and innovative practices.

Joy Rumble is an assistant professor of agricultural communication within the Department of Agricultural Education and Communication at the University of Florida. She focuses her efforts in the Center for Public Issues Education in Agriculture and Natural Resources where she conducts research and outreach initiatives around effective communication in agriculture. Her research concentrates on consumer perceptions of agriculture and has included studies examining perceptions of local food, food safety, GMOs, livestock legislation, and transparent communication in the livestock industry.

Ricky Telg is a professor in the Department of Agricultural Education and Communication at the University of Florida and the director of the Center for Public Issues Education in Agriculture and Natural Resources. His research interests include agricultural communication (television/ video production, print media, and media relations) and distance education (instructional design, instructional media).

Alexa Lamm is an assistant professor in the Department of Agricultural Education and Communication at the University of Florida and the associate director of the University of Florida/ Center for Public Issues Education in Agriculture and Natural Resources. She specializes in conducting research on agricultural and natural resource public policy implementation and the use of evaluation methodology as it applies to programmatic and organizational change theory. Her research areas of interest include public opinion analysis of agricultural and natural resource issues, cognitive impacts on decision-making processes, opinion leadership of agricultural and natural resource issues, and measuring impacts of educational initiatives. 